\title{
RESENHA
}

\section{IDÉIAS "RICAS" APOIANDO O TURISMO}

\author{
Beatriz Helena Gelas Lage
}

RABAHY, Wilson A. PLANEJAMENTO DO TURISMO - Estudos Econômicos e Fundamentos Econométricos. Edições Loyola, São Paulo, 1990, 167 p.

Com muita propriedade o livro do Professor Wilson Rabahy condensa sua tese de Livre-Docência, defendida na Escola de Comunicações e Artes da Universidade de São Paulo. Sua proposta atinge um objetivo maior em transmitir aos estudiosos do turismo alguns dos aspectos específicos da economia e dos fundamentos econométricos do planejamento turístico. Trata-se de uma área pouco explorada e pouco reconhecida com a devida seriedade, conforme afirma, ná apresentação, o Professor Roberto Macedo, da Faculdade de Economia e Administração da Universidade de São Paulo. O autor se destaca como um dos pioneiros nesse campo de estudo, e distribui a análise nos seis tópicos de seu livro.

A primeira parte retrata a evolução e a situação do turismo mundial, ilustrada estatística e graficamente, evidenciando, de forma empírica, o movimento físico dos turistas a nível mundial e da respectiva receita gerada intemacionalmente. Acrescenta em sua abordagem algumas características dos principais países emissores de turistas, e também de outras peculiaridades dos principais países receptores do turismo mundial.

I ogo a seguir, na segunda parte, faz uma análise bastante atualizada da economia brasileira e de seu relacionamento com o setor turístico, enfatizando, entre outros aspectos, a situação real do Balanço do Turismo Internacional no Brasil, em termos de Receitas e Despesas na última década.

$\mathrm{Na}$ terceira parte, inicia uma abordagem teórica onde apresenta, de forma descritiva, os principais efeitos econômicos e sociais do turismo, destacando a importância desses impactos em estratégias de desenvolvimento econômico e de apoio ao planejamento turístico. Complementa a sua análise com a discriminação dos efeitos socio- 
culturais e ambientais do turismo, demonstrando preocupação ao enfatizar sua interação com outras áreas de estudo.

A seguir, na quarta parte, classifica os principais fatores que afetam o desenvolvimento do turismo, tais como: fatores sócioeconômicos; fatores culturais e psicológicos; fatores técnicos. Salienta o enfoque com idéias claras e exemplificadas, com o devido cuidado ao destacar a enorme dicotomia exisiente entre o turismo dos países desenvolvidos e dos países em desenvolvimento.

$\mathrm{Na}$ quinta parte, propōe o uso de modelos econométricos no turismo, indispensáveis ao planejamento, apresentando alguns exemplos utilizados no trabalho de M.F. Palomo (Economia Turistica. Tesis Doctoral, Madrid, IMNASA, 1979).

Conclui essa análise econométrica com diversas sugestōes de outras aplicaçōes, tais como técnicas de análise secular, construção de variáveis sazonais, construçāo de indicadores de custo de vida no turismo, aplicação de modelos gravitacionais, e cálculo dos multiplicadores de renda.

Por fim, na sexta parte, formula um modelo de previsāo de fluxos turísticos internacionais no Brasil, com interessantes aplicaçōes para estimar o número de turistas da Argentina, dos Estados Unidos e da Alemanha que ingressaram anualmente no Brasil, no período de 1971 a 1986.

Em síntese, a obra Planejamento do Turismo oferece um manancial de informaçōes para todos aqueles que buscam novas fontes para desenvolverem pesquisas e estudos sobre o turismo, que representa uma das mais importantes atividades econômicas no mundo atual. 